quite intelligible if we regard the cyclone region of the Chinese Sea as an extension of that of the Bxy of Benzal; it will then be seen that the cyclones follow the sun. This, however, must be understond with the qualification that they follow the sun at some distance; the number of cyclones in the Intian Ocean appears to reach its maximum a month or two after the equinoxes. This is for the same reason that the warmest period of the year is not at but after Midsumner.

The distribution of cyclones in the West Indian Seas is to be explained in the same way. The two trade-winds meet in the Atlantic a little to the north of the e putor; for this reas.m cyclone; are frequent in the West In lies but unknown over the Soutn Atlantic, and they are most numerous at the end of summer.

Oid Forge, Dunmurry, Co. Antrim Joseph John Murphy

\section{Saturn's Rings}

AN absence in the country prevented my seeing Lieut. Davies's letter in time for an earlier reply. I will ans $\wedge^{*}$ er him on all pisints, and have done with him, for he employs unfair arguments to impeach me.

I. I defy him to point out the smallest word or slightest expression in my remarks on his work that justifies hin in as ierting "that I commenced my notice very much und $\cdot r$ the impression that Prof. Clerk Maxwell having investigated the stanility of Saturn's rings, no one else is to veniure into any discussion on their nature and origin." I never for a moment $\in$ ntertained, much less expresied, such a thought. I simply pointed out that Prof Maxweil had shown rings of satellites to be the only ones which could exist, and I said merely that Lient. Davies, "having espoused this theory. had sought an explanation" of it. Lieut. Davies's allusion to a caveat is therefore an empty fl, mrish.

2. Lieut. Davies says I "assert" that he has not seen Prof. Maxwell's work. Tni: is an unpurdonable misstatem nt. I said he "appears not" to have seen the work; and I was driven to this assumption, since Lieut. Davies, while actually using Maxwell's labours, never mentions his name. Certainly he is at liberty to choose his own starting point : but he should credit the well and not the bucket (Mr. Proctor will pardon me) for hi inspirng draught.

3. As to faith in figures. I take for $\mathrm{g}$ anted that no rational man would publish numerical data unl $\mathrm{ss}$ he believed his figures really to mean what they stand for. Now, the rate of the solar motion is not known to within a thousand miles an huru, and the solar parallax is only certain to the first place of decimals. As Lieut. Davies prints the first of these data to a mile, and the secund to four decimal places, he has clearly too great faith in figures He may say that "other observers" (why observers?) do the same; that does not excuse hım. Further, a different rate of solar motion must alter his spirals; if there were no motion he would have no spiral.

4. I know that "very clever men" have held the meteoric theory of the sun, but I also know that "very clever men" have held other theories. Lieut. Davie;, in denying my assertion that he is "blindly enraptured" wirh the me eoric theory, actually supports me; for when he says that "none of the modern theories, 'cumbrous vagaries of the brain,' can compare with it," it is clear that he cannot see the fairness of any crow but his own, and this is blind infatuarion.

5. Either we are not agree:1 upon the meaning of "cyclonic," or Lieut. Davies is sun-spot blind. I call such a spot as that reproduced on page 232 of Mr. Proctor's bouk "cyclonic," and I have seen miny, both on the sun and in $\mathrm{d}$ awings, of bis character. Lieut. Davies's range of observation must be limited if he has not seen sume also. Mr. Carring on's work is quire beside the question; he did not delineate spots, he merely measured and counted them.

YOUR Reviewer

\section{Extinction of the Moa}

THE very interesting article on the Moa in your issue of July 6 th by Dr. Hector adds considerably to the facts already asce: $\mathrm{r}^{-}$ tained as to its existence along with man, and also as to the probability of its recent disappearance. Vistting in 1866 and 1867 many of the places mentioned by the Doctor in the Middle Island, I had opportunities of seeing portions of therr remains in various conditions, either in caves, river sides, or in the open country where cultivation was yoing on, or on the sides of the hills in the interior, and certainly the impression produced was, that not perhaps more than fifty years had elapsed since some of the remans had formed part of living hirds.

On the Kourow range of hills in the north of Otago, I saw Moa bones and thuse of a wild pig in close proximity; and, though certainly those of the former were more weatheret, raking into consideration the greater density of the latter, it did appear as if there had noi been a great many years between the death of each. I have also some bones in my possession, and there are others in the Geological Society's Museum in Edinburgh, fount on the surface of the Carrick ranges, a place alluded to by Dr. Hector, the unexposed portions of which do not seem very aged. While agre ing with Dr. Hector that there is reason to believe that the last of the race have only of late disapueared, viewing the question from the point of an agriculturist, I differ somewhat as to the causes. He says that the facts he adduces "afford strong evidence that the bird has hein exterminated by human agency, though the race was expiring from numulal causes." It seems to me that in such a country as. New Zeaiand their loss has arisen from natural causes, thou hh the Aboigines may hive assisted somewhat to diminish their number. Dr. Hector a tmits that there are still portions of Otago where the foot of man has scarcely trod, notwithstanding the search for gold, perraps the most eager which can exist. The Moa had these districts to retire to. In the Middle Island very few Manries dwelt, and their numbers were kept down by the forays of the mure warlike inhabilants of the North I-1and. The pigs, supplied to the natives by Captain Cook, have spread over the island and increased largely, and have only been prevented irom still furth: 1 increasing by the use of the musket and the occupation of the country by the settlers. While the Kiwi still muntains i s place, it is hard to believerhat man basexter:minated the Moa. Thenatural causes, however, it seems to me, are quite suffictent. Dr. Hector speaks of lar $r_{z} \mathrm{e}$ fire having spread over the centre of Otago. It would appear that the pine woods, which have covered so many of the hill sides of the interior, had rrached a certain sta.e of decay, and, frum the occurrence of droughts less severe than those of Australia, perhaps, fires lighted by the natives had spread to these woods, and though an under rowtin of fern and moss might re ard the progress when once the pine timber, with its resinstus qualities, thoroughly caught, there was little chance of it going out save frum breaks caused by rivers or bare places. As these fires spread over the interior, destroying everything in the shape of bu.h or tree, the native grasses took their place, none of which seemed to me to afford fit ing food for such a bird, and with these grasses a plant calied by the native Tutu occupies muih of the country. The leaves of this plant a e, under certain conditions, destruccive to live stock; while the berry which it produces uay be eaten with impunity, provided the stone it contains be not swallowed; the stthis making a wholes nne jelly of the pulp, and sometimes wine. Here, then, we have a vast portion of the country cleared of its food supplies, from the trees and shrubs which produced it being destroyed, and we have a poisonous plant abumding, which does not grow freely under wrood. Dr. Hector speaks of counting thirtyseven skeleton heaps of Mo is on the side of the Wakatipu Lake, and supposes that they had been driven there by fire. This may be so, but $I$ have seen a great many similar heaps, in the centre of each of which two or three handfuls of quartz pebbles lay on the flat alluvial lands on the sides of $\mathrm{s}$ reams and near the seashore, where beds of gravel then were, to which the birds could have retired, had they been pressed with fire, as no vegetation could have existe $:$ there. It therefore seems to me that the reason why so many slieletons are found on the surface near streams or water, arises from the fact that these creatures, pressed by hunger, partook of the Tutu berries, and that thirst, which so often accom panies poisoning, caused them to take to such places for drink. I have heard it stated that in periods of drought the Emus of Australia travel great distances for water. 'Though water is far more abundant in New Zealand, it is often only in the streams that it can be had.

James MeLvin

\section{NOTES}

THe following is the programme of the subjects to be submitted for discussion at the International Congress of Anthropology and Archzol gy, to be held at hologna from the Ist of October next:-The stone age in Italy; 2. The caverns of the shores of the Mediterranean, especially of Tuscany, compared with the caves of the sontl of France; 3 . The lake habitations 